\title{
Peer Trainers Are Change Agents as Well as Instructors: Promoting Safety and Health in the Workplace
}

\author{
Ruth Ruttenberg ${ }^{1,2 *}$, Don Dudley ${ }^{3}$, John Morawetz ${ }^{4}$ \\ ${ }^{1}$ Ruth Ruttenberg \& Associates, Northfield, Vermont, USA \\ ${ }^{2}$ School of Management and Labor Relations, Rutgers University, New Brunswick, New Jersey, USA \\ ${ }^{3}$ Department of Transportation Coordinator, Center for Worker Health and Safety Education, International Chemical Workers \\ Union Council, Cincinnati, Ohio, USA \\ ${ }^{4}$ Director, Center for Worker Health and Safety Education, International Chemical Workers Union Council, Cincinnati, Ohio, USA \\ Email: ^rruttenberg@tds.net
}

How to cite this paper: Ruttenberg, R., Dudley, D., \& Morawetz, J. (2020). Peer Trainers Are Change Agents as Well as Instructors: Promoting Safety and Health in the Workplace. American Journal of Industrial and Business Management, 10, 677-688. https://doi.org/10.4236/ajibm.2020.103045

Received: February 1, 2020

Accepted: March 23, 2020

Published: March 26, 2020

Copyright $\odot 2020$ by author(s) and Scientific Research Publishing Inc. This work is licensed under the Creative Commons Attribution International License (CC BY 4.0).

http://creativecommons.org/licenses/by/4.0/

\begin{abstract}
Peer trainers from across the country, who worked on road crews, in hospitals, in prisons, and in chemical facilities, themselves brought positive safety and health changes to their workplaces. Through advanced instruction, at the International Chemical Workers Union Council (ICWUC) Center for Worker Health and Safety Education (the Center), they not only learned how to be health and safety instructors, but they also became change agents by responding to questions on the shop floor and taking actions to improve safety and health for themselves and for their fellow workers.
\end{abstract}

\section{Keywords}

Peer Trainers, Change Agents, Occupational Safety and Health

\section{Setting}

The clear objective of safety and health training is to improve safety and health in the workplace. Beyond awareness, knowledge, and hands-on skills, the objective is to encourage individuals when returning to their workplaces, to make a difference and improve safety and health. A survey, a classroom exercise, and class discussion in September 2019, at the Center asked fourteen experienced worker trainers to share the impacts of their initial training on the health and safety of their workplaces. They came from three unions and eleven states and the District of Columbia. ${ }^{1}$ Their jobs were on road crews, in hospitals, in prisons, ${ }^{1}$ Arkansas, California, Colorado, District of Columbia, Illinois, Indiana, Michigan, Minnesota, Nevada, West Virginia, and Wisconsin. 
and in chemical plants.

The focus of this report is around two major contributions that these trainers make to their workplaces around the country: 1) when there are questions from co-workers and management, they are often the "go-to" people, because of their knowledge of safety and health and 2) they are able, based on their knowledge and commitment, to help make workplace improvements that better protect safety and health for themselves and their co-workers.

\section{Literature Review}

There is evidence that worker trainers, themselves, may be active as change agents in their own workplaces. While there is an abundance of literature about traditional teachers as change agents in curriculum development, of health care workers active as change agents in communities, and of workers encouraging social change; there is a scarcity of published literature on worker trainers as change agents. There are, however, some case studies that tell the story. The ICWUC Center recently documented that worker trainers, trained through a Department of Energy (DOE) grant, have become subject matter experts at their facilities, relied on by both management and fellow union members (Morawetz, Frazee, \& Ruttenberg, 2020). Previous evaluation work ICWUC found that active and educated workers help to improve the environment (Becker \& Morawetz, 2004 and McQuiston, 2000). These studies found that after training, workers are more active participants in improving their health and safety, are more willing to attempt to change worksite conditions following training, and their efficacy at making changes is substantially greater than before they were trained. Two other ICWUC studies reported success in systematically addressing worksite hazards after joint labor management programs trained the entire workforce in OSHA classes assisted by site trainers (Mahan et al., 2014 and Mahan et al., 2018). This paper moves a step beyond to explore increased learning and activism from the continuing presence of a group of worker trainers on the shop floor, building an increasing infrastructure for making safety and health integral to daily activities.

The Railway Workers Hazardous Materials Training Program at the National Labor College (Ruttenberg \& Lazo, 2006) collected scores of anecdotes from peer trainers about changes they helped institute at their rail yards, along the track, and in trains to improve safety and health. These included initiating OSHA inspections, putting barriers up around stationary propane tanks, getting windsocks, not letting trains leave without proper paperwork, and applying NFPA labels to flammable/combustible storage cabinets and storage areas.

There are other examples, focusing more on getting the participants in training to be agents of change in their workplaces: 1) A program at a facility organized by the United Auto Workers found that: "The committee members' role has evolved from being merely recipients of training to conducting training themselves, and, more recently, to being partners in the design of new pro- 
grams... these opportunities have strengthened their skills as trainers, as change agents, and as health and safety activists in their workplace." (Kaminski, Graubarth, \& Mock, 1995); 2) Health and safety trainers from the American Federation of State, County and Municipal Employees (AFSCME) found that using an organizing model of unionism for health and safety training generated health and safety activism in the membership (Siqueira \& Marquardt, 1995); 3) Health and safety training, through a consortium of California and Arizona universities, involving workers and worker trainers also had success in promoting workplace change: "The workers, all from the same shop, gather around a large sheet of paper taped to the wall. One of them is sketching the shop's floor plan and marking where certain health and safety hazards are. The other workers are giving her guidance-'Don't forget the vapors from the degreasing tanks,' 'Remember the oily spot on the floor the custodians always miss,' 'There's the noise from the punch press.' Later they will decide where they want to start to make changes in their workplace." The assumption was that training would increase knowledge and skills, and also promote workplace changes to better protect safety and health (Brown, 1995).

Lunenburg, after an extensive literature review, said, "A change agent is anyone who has the skill and power to stimulate, facilitate, and coordinate the change effort." (Lunenburg) He established key factors for successful change agents, and most seem tailor-made for worker trainers:

- Similarity between change agent and employees.

- Empathy, or understanding the feelings of another person, which leads to improved communication and understanding between the change agent and organization members.

- Linkage, or the extent to which the change agent and organization members are tied together in collaborative activities.

- Proximity, or physical and psychological closeness of the change agent and organization members.

- Structuring, or the ability of the change agent and organization members to plan and organize their activities.

- Reward, or the nature and variety of potential positive outcomes of the change.

- Energy, or the amount of physical and psychological effort the change agent and organization members are able and willing to expend on change.

- Capacity of the organization and openness of the organization to change are two other factors that go beyond worker trainers.

- Synergy, or the presence of positively reinforcing effects that each of the above factors has one on the other.

Peer trainers can be effective change agents because they are respected members at their workplaces. A study by the Cornell University ILR School found that peer trainers were trusted and familiar with local situations. The Cornell study concluded that "peer trainers are familiar with the local situation and can give specific advice about the local market." (Cornell University, 2008) 


\section{DOT HMIT Grant}

Initially funded in 2009, the ICWUC has been continuously awarded one year Hazardous Materials Instructor (HMIT) grants from the Pipeline and Hazardous Materials Safety Administration (PHMSA) of the Department of Transportation (DOT). These are train-the-trainer grants that are awarded to nonprofit organizations who have expertise in conducting training programs for hazmat employees, and the ability to reach and involve in a training program a target population of hazmat employees. Eligible hazmat workers as defined by 49 CFR 171.8, participate in a 5-day train-the-trainer program based on the DOT Emergency Response Guidebook (ERG) and a "toolbox" to assist these trainer/instructors in teaching on the ERG, hazmat basics, regulations, chemical properties, toxicology, shipping papers, placards, responder resources and security awareness. Trainers practice presentations and then return to their workplaces to conduct toolbox training.

\section{Results}

Fourteen peer trainers attended a 40-hour Technical Skills course in September 2019 and all had previously taken the Department of Transportation (DOT) Train-the-Trainer (TTT) course and done toolbox training at their own work sites. In addition, some had taken Chemical Emergency Response (CER) and CER train-the-trainer courses. Eleven of the 14 had completed the basic HMIT TTT training within the last year; the other three in the last one to three years (see Table 1). All but one had done training alongside Center staff in the last year and 10 of the 14 at least twice during the year. Two said they trained alongside Center staff at least once a month (see Table 2). All but one had also done training without Center staff at least twice a year. Four had done training without Center staff at least every month (see Table 3).

Table 1. How long ago did you go through the center's basic dot train-the-trainer program?

\begin{tabular}{ccc}
\hline & Number & Percent \\
\hline Within the Last Year & 11 & $78.6 \%$ \\
One to 3 Years Ago & 3 & $21.4 \%$ \\
\hline
\end{tabular}

Table 2. How often have you trained in the last year, with center staff?

\begin{tabular}{ccc}
\hline & Number & Percent $^{*}$ \\
\hline At Least Every Month & 2 & $14.3 \%$ \\
At Least Every Two Months & 1 & $7.1 \%$ \\
At Least Every Six Months & 7 & $50.0 \%$ \\
At Least Once a Year & 3 & $21.4 \%$ \\
Less Than Once a Year & 1 & $7.1 \%$ \\
\hline
\end{tabular}

${ }^{\star}$ May not add to $100 \%$ due to rounding. 
Table 3. How often have you trained in the last year, without center staff?

\begin{tabular}{ccc}
\hline & Number & Percent $^{*}$ \\
\hline At Least Every Month & 4 & $30.8 \%$ \\
At Least Every Two Months & 4 & $30.8 \%$ \\
At Least Every Six Months & 4 & $30.8 \%$ \\
At Least Once a Year & 0 & $0 \%$ \\
Less Than Once a Year & 1 & $7.7 \%$ \\
\hline
\end{tabular}

${ }^{\star}$ May not add to $100 \%$ due to rounding.

After returning to work, following initial TTT training, all but one peer trainer (nearly 95 percent) had been asked safety and health-related questions by other workers in the last year and eight of 14 (over 55 percent) were also asked safety and health questions by a member of management (see Table 4). Questions asked of them ranged from proper chemical storage to chemical properties, from appropriate personal protective equipment (PPE) to regulatory requirements. Most felt confident about giving answers, but if they needed help, they went to staff at ICWUC, used ICWUC materials, CFRs, got information from National COSH, and/or did their own research.

Of the 13 who received questions, more than 30 percent were asked questions every week and another 60 percent were asked questions every month. These trainers were "go-to" people in their facilities-an invaluable resource for better health and safety.

Eighty-five percent were asked questions about safety issues such as hearing protection and machine guarding, mostly on a monthly basis. Almost 70 percent were asked questions about personal protective equipment (PPE), at least 30 percent every week. Eighty-five percent were asked questions about chemical properties-nearly 20 percent on a weekly basis and another 45 percent on a monthly basis. There were questions about chemical storage, bloodborne pathogens, Hepatitis B, industrial power equipment, slippery floors, chemical transport, traffic control, storage, and contaminated water coolers.

Their priorities for making the workplace safer focused mainly on education, more and better training at work, and getting management to take part in training. They also wanted more materials from the ICWUC Training Center.

Trainers were frequent users of health and safety resources. More than 90 percent had used the DOT Emergency Response Guidebook (ERG). More than 70 percent had used the Center's DOT resource manual and the NIOSH Pocket Guide in the last six months. More than 60 percent had used 49 CFR (DOT) and the New Jersey Hazardous Substance Fact Sheets. All said they had used Safety Data Sheets and the Internet (see Table 5).

Which health and safety web sites were most used? In order of response: DOT ERG and Safety Data Sheets; NIOSH, Centers for Disease and Prevention (CDC), and New Jersey Fact Sheets; Plant Intranet; 49 CFR; and Pipeline and Hazardous Materials Safety Administration (PHMSA). Over 55 percent use Safety and Health apps on their phone (see Table 6). 
Table 4. In the last year have you been asked by other workers about.

\begin{tabular}{cccccc}
\hline & Yes & Every Week & Every Month & Less than Monthly & No \\
\hline Safety & 13 & 4 & 8 & 1 & 1 \\
PPE & 9 & 4 & 3 & 2 & 4 \\
Chemical Properties & 12 & 2 & 5 & 5 & 2 \\
Other Health and Safety & 14 & 5 & 3 & 2 & 0 \\
\hline
\end{tabular}

Table 5. Have you used any of the following resources in the last six months?

\begin{tabular}{cccc}
\hline & Yes Number & Percent & No \\
\hline ICWUC DOT Resource Manual & 10 & 71.4 & 4 \\
NIOSH Pocket Guide & 10 & 76.0 & 3 \\
DOT Emergency Response Guidebook & 12 & 92.3 & 1 \\
49 CFR (DOT) & 8 & 61.5 & 5 \\
New Jersey Hazardous Substance Fact Sheets & 8 & 66.7 & 4 \\
Safety Data Sheets & 13 & 100.0 & 0 \\
\hline
\end{tabular}

Table 6. Have you used health \& safety web pages in the last six months? Nine of 14 $(64.3 \%)$ said "yes". if "yes," which sites have you accessed?

\begin{tabular}{ccc}
\hline & Number & Percent \\
\hline DOT ERG & 7 & 77.8 \\
SDS & 7 & 77.8 \\
CDC & 6 & 66.7 \\
NIOSH & 6 & 66.7 \\
Plant Intranet & 3 & 33.3 \\
Other & 2 & 22.2 \\
PHMSA & 1 & 11.1 \\
\hline
\end{tabular}

The biggest obstacles to doing training, each listed by at least one individual, were management issues, followed closely by lack of interest by workers. Insufficient time, union issues, and not yet being comfortable with the materials were other issues mentioned.

\subsection{Helping to Make Workplace Changes to Improve Safety and Health}

Peer trainers had many stories to tell about how training had helped them resolve safety and health issues at work. They also spoke of some of their training activities. Some were directly related to PHSMA and others to broader safety and health issues.

\subsubsection{Training Activities}

An AFSCME member spoke of doing ERG review in Spanish and how grate- 
ful members were for the information. They wanted copies of the ERG and the trainer wants to be able to provide the entire DOT TTT in Spanish.

"More awareness to 49CFR100-185 has been covered since the June DOT class. We have management support and are implementing many and varied safety training classes to the employees."

"New employees. One of the topics is hazard communication. I teach new hires that include hourly, salary, and management employees about GHS requirements, GHS pictograms, how to access SDS sheets and also New Jersey Fact Sheets. The New Jersey Fact Sheets (NJFSs) were introduced to my site by ICWUC Center for Worker Health and Safety educators. Our employees like the NJFSs and our site has access to them on company intranet. Also available is the electronic version of the ERG. ERGs are provided now to all departments and on the emergency response vehicles at the plant."

One peer trainer spoke about how his co-workers did not want to hear about OSHA, but they felt differently about DOT. "After taking the DOT TTT class I was able to discuss some of the same OHS issues from another direction and get some traction. This has opened a number of doors for further discussions and opportunities to provide training. One was a local labor council that has pledged to open each monthly meeting of the delegates with a part of the training."

\subsubsection{Workplace Benefits and Outcomes of Training}

$>$ "My experience was that one day I had returned to the yard and 20 of my fellow coworkers came to get me. They brought me to the leader of the herbicide sprayer crew. He had somehow gotten covered in herbicide. I told him to wash it off. After he had cleaned up, I spoke with him about toxicology and how carcinogens build up in the body causing cancer. After our talk he started wearing his proper PPE. He also talked to his crew and had them start wearing PPE."

$>$ "Prior to training here at ICWUC I had heard of PCBs, but never knew how to respond to a spill with possible PCBs. After attending training at the Center, when we had a transformer overturn, I was able to guide my co-workers in the proper procedures for containment and clean-up of a small (10-15 gal) spill. Having been trained on the Emergency Response Guide I was able to obtain and direct the use of the proper PPE, as well as properly labeling the Hazardous Waste drums."

> "In my department we used propane tanks that weren't stored in a single location. They used to be placed all over the garage. We had employees almost run over the tanks or back up over them because people would just sit them next to trucks or right by the overhead door of the garage. I went to my manager and we decided to put them in a cage outside with a lock on it so when someone needed it they had to get the key and they will be held accountable if they don't put it back in the cage."

A peer trainer spoke of being sure that residual material from a 55-gallon 
drum was totally cleared from it, so it could be transported safely. Knowing the regulations was important in this task.

"Bloodborne pathogens and sharps (needle sticks) exposures were occurring with not correct disposal methods used during homeless encampment cleanups. Fix: Since training, proper disposal containers and methods are used for cleanup. Also, Hepatitis B shots are now offered to employees."

"I use the New Jersey Fact Sheets to show the effects of inhaling the fumes from the asphalt they use and how it can cause cancer and now more employees are using masks when working pothole patching."

$>$ "After the training I had just received, I was involved in a warehouse inspection and during the inspection we came across the flammable storage lockers. As we started inspecting the contents inside the lockers, we noticed some of the chemicals were stored together and should not have been. As the inspector was reading a label on one of the chemicals, he noticed the exclamation mark and stated, 'I know this shouldn't be I here. This symbol means highly flammable.' As he said it, it caught my attention. I just had the DOT training on the hazard classes, placards, and labels. I replied no I'm sure that symbol has to do with toxicity. Had I not taken the course I probably would have believed him, so after learning what hazard classes can and can't be stored together, I've had new flammable and corrosive lockers installed and chemicals separated. Once our Chief of Logistics heard about the incident he stated he didn't know I was taking classes and he would make sure to contact me if he had hazmat questions or concerns and wanted me to brief him on the outcome of the storage and locations of the new locker."

> "I attended the DOT Train the Trainer course ... at the Center in Cincinnati. Shortly after my return, I arranged training session for a group of five employees. I used the excellent Toolbox that was given to us at the training. This group had never had anything like this before. When I got to the section that detailed incompatible chemicals, one of the participants suddenly jumped up and said, 'I'll be right back.' We were mystified about her abrupt departure. When she returned a few minutes later, she explained that while I was giving details about why types of chemicals could not be stored near others, she realized that in a storage area in our closet, she had inadvertently put some cleaning solvents that were professional grade in the same cardboard box as other items that could have caused a reaction. The timing was significant because she brought the solvents in just the day before in preparation of a deep clean, we had planned for the office. The discussion then turned to one of what types of products we have stored together in our homes. Everyone was shocked to learn that having bleach and ammonia could cause fumes or an explosive liquid. This training was very important as it potentially averted a disaster at work and at home. The employees were so thankful for the training and the useful information that they could take home."

"This class was very informational, and I took the knowledge back to my place of employment. For years we were using diesel fuel for working with 
asphalt. It would clean the mix of tools and the hot box very, very good. The hot box was designed with a heating system much like a gas furnace in your home with 2 propane tanks on the front and a box on the back that held the diesel fuel for cleaning shovels. One day in the late fall a patch crew was patching when an employee dipped his shovel in the diesel fuel to clean it. $\mathrm{He}$ opened the door to the hot asphalt tuck shovel in the mix. A flash back occurred and burned the man's hair off his face and melted his safety vest to his body. Because of the DOT training I received [my city] now longer uses diesel [fuel] for they have changed city policy about this."

$>$ “I've learned about truck placards, recognizing what kind of cargo is on the road. I've taught family members, friends, and inmates the meaning of the label code. I even taught my twelve-year old son how to use the ERG app on his cell phone to look up and identify numbers from a placarded truck. I would ask him what kind of hazardous material was in the truck."

"Taking the DOT Train-the-Trainer a few years ago I learned that not all of our employees were learning about a lot of the important information about hazmat training. Back years prior to this training, only emergency response e-crew employees received hazmat training. Now and in the past few years, all operators, department chemical foremen, and e-crew employees receive the initial Hazmat training course and then every year after the employees sit through an 8 -hour refresher. This training is handled by a $3^{\text {rd }}$ party contractor, but I have mentioned to management that the training I have received from the ICWUC Center for Worker Health \& Safety Education could allow myself and any others that have or could receive this training allow our own employees to teach our own. The $3^{\text {rd }}$ party teaches the course with the NIOSH Pocket Guide, SDS on our own chemicals, and uses the Emergency Response Guidebook. All of these resources along with the using and comparing exercise that the Center taught me and others to use would make the class site-specific."

After a fire, one peer trainer got a call from an employee asking who would clean up the soot. The peer trainer brought industrial hygiene and the safety manager together with union leadership. As a result of health and safety training a specialized $3^{\text {rd }}$ party contractor did the clean-up.

At a long-term care facility, there is now PPE for dressings and nuclear medicine and gloves have changed from latex to nitrile.

$>$ Management was supposed to be doing 40-hour hazwoper training, but employees were only getting one hour. Now they are doing real training. It's easier to get PPE and gloves are puncture resistant.

A peer trainer got rest periods for employees suffering from heat in Tyvek suits.

$>$ “The Department of Veterans Affairs has experienced a high rate of needle sticks along with exposure to biohazard waste from employees working in environmental services. The incidents were happening because of the way employees were handling what are called red bags holding needles and waste 
material. Prior to providing education on the proper procedures, for packaging, the Veteran Affairs had to pay employees as far back as 10 years ... the handling and packing of hazardous waste material according to DOT regulations, along with OSHA, have minimized the number of needle stick exposures and have decreased. Monthly I take part with safety and emergency meetings to view any incidents that occurred along with whatever solutions took place."

Other Reports:

One peer trainer organized his facility's SDSs. Management said there were 960 chemicals (from a $3^{\text {rd }}$ party inventory assessment), but in reality, there were 1166 chemicals.

One peer trainer said there used to be a safety tour every month. They would go to each department and bring up issues. Now there are two safety tours every month.

One peer trainer reported a cabinet full of incompatibles and that was resolved.

> One agency where a peer trainer worked wanted only electronic copies of SDSs, but the union negotiated for hard copies in the garage and electric shop.

$>$ Specimens at one facility were stored in the break room refrigerator. That is no longer the case.

Blood labs at one facility were not properly packaged and there were issues with blood pathogens and exposed needles.

Peer trainers told of new storage cabinets for corrosives, better storage of propane, better gloves, soap and clean water on their trucks, better labeling for forklift drivers, presence of GHS in the tool box, more labeling, increased existence of 300 logs, safety reports at union meetings, use of shipping labels, and storage cabinets cleaned out.

> "I teach friends of mine with kids about chemicals with the toolbox and now they check the hazmats in the chemicals they buy for cleaning and they also put the cleaning supplies high in their cabinets where they know the kids can't get to it."

\section{Discussion}

Worker trainers are more than just trainers. As peers, they are trusted and "go to" people at work. Their knowledge through the ICWUC's education program is a critical building block in the ability to act and effectuate change in the workplace. As the literature suggests, change in an institution comes best from those who are connected to an institution and are trusted and respected in their position and knowledge.

The Center for Health and Safety Education at the International Union of Chemical Workers Council has long had a focus on how worker trainers develop, both as instructors and as change agents in their work places. In 2018 the Center studied the actions of worker trainers in Department of Energy facilities 
where the ICWUC or the International Association of Machinists and Aerospace Workers represents workers. Under the DOE grant a group of 6 to 10 workers trainers have been developed who are funded by the grant to conduct worksite training. This paper studies worker trainers receiving training through a Department of Transportation grant that only develops one trainer per worksite and does not support worksite training. In the future, the hope is to further explore the activities, back on the shop floor, of worker trainers involved with the either the DOT or National Institute of Environmental Health Sciences Worker Training Program (NIEHS) grants. A major goal of this on-going research is to explore how trainers develop, how they become workplace experts and what they believe will enhance their site abilities.

There were management questions to the peer trainers as well as fellow workers. Still, getting the time to change and having the ear of management were persistent problems expressed by the peer instructors. Having ICWUC staff available for advice in instruction helped solidify their roles as peer trainers. There is still more work to do, to enhance the training and to encourage both worker and management participation in workplace safety and health.

Limitations of this research include the small sample size of peer trainers who were surveyed. Longitudinal research is recommended for the future.

The practical significance and main contribution of this work is that peer trainers, returning to work, can become effective change agents as well as effective instructors. They also become important informational sources to both their shop floor colleagues and to management.

\section{Conclusion}

Peer trainers from 3 unions in 11 states and the District of Columbia not only learned how to be health and safety instructors in their workplaces, but they also became change agents by responding to questions on the shop floor and taking actions to improve the safety and health of those they work with.

\section{Acknowledgements}

The project described was supported by Hazardous Materials Instructor (HMIT) grant number $693 \mathrm{JK} 31840002$ from the Pipeline and Hazardous Materials Safety Administration (PHMSA) of the Department of Transportation (DOT). Its contents are solely the responsibility of the authors and do not necessarily represent the official views of the DOT.

\section{Conflicts of Interest}

The authors declare no conflicts of interest regarding the publication of this paper.

\section{References}

Becker, P., \& Morawetz, J. (2004). The Impacts of Health and Safety Education: Compar- 
ison of Worker Activities before and after Training. American Journal of Industrial Medicine, 46, 63-70. https://doi.org/10.1002/ajim.20034

Brown, M. (1995). Worker Risk Mapping: An Education-for-Action Approach. New Solutions: A Journal of Environmental and Occupational Health Policy. https://doi.org/10.2190/NS5.2.e

Cornell University, ILR School. (2008). Training for Success: A Guide for Peer Trainers. DigitalComons@ILR, Gladnet Collection. 2008.

Kaminski, M., Graubarth, R., \& Mock, A. (1995). Using Grant-Based Training as a Vehicle for Lasting Change: Strengthening the Role of Local Health and Safety Activists. New Solutions: A Journal of Environmental and Occupational Health Policy. https://doi.org/10.2190/NS5.2.c

Mahan, B., Maclin, R., Ruttenberg, R., Mundy, K., Frazee, T., Schwartzkopf, R., \& Morawetz, J. (2018). Labor-Management Cooperation in Illinois: How a Joint Union Company Team Is Improving Facility Safety. New Solutions: A Journal of Environmental and Occupational Health Policy, 28, 227-239.

https://doi.org/10.1177/1048291118759303

Mahan, B., Morawetz. J., Ruttenberg, R., \& Workman, R. (2014). Workplace Safety and Health Improvements through a Labor/Management Training and Collaboration. New Solutions: A Journal of Environmental and Occupational Health Policy, 23, 561-576. https://doi.org/10.2190/NS.23.4.c

McQuiston, T. H. (2000). Empowerment Evaluation of Worker Safety and Health Programs. American Journal of Industrial Medicine, 38, 584-597. https://doi.org/10.1002/1097-0274(200011)38:5\%3C584::AID-AJIM11\%3E3.0.CO;2-H

Morawetz, J., Frazee, T., \& Ruttenberg, R. (Pending Publication 2020). Worker Trainers as Workplace Experts: How Workers Trainers Enhance Safety and Health and Department of Energy Facilities. Labor Studies Journal. https://doi.org/10.1177/0160449X19868771

Ruttenberg, R., \& Lazo, M. (2006). Fifteen Years of Documented Success: Rail Workers Hazardous Materials Training Program, 1991-2005. National Labor College.

Siqueira, C. E., \& Marquardt, W. G. (1995). Twelve Years to a Safer Workplace. New Solutions: A Journal of Environmental and Occupational Health Policy.

https://doi.org/10.2190/NS5.2.d 